\title{
The Impact of Audit and Governance Committee on Internal Shariah Audit Performance: An Islamic-Worldview based
}

\author{
Azam Abdelhakeem Khalid
}

\begin{abstract}
It is this study's goal to conceptually examine the impact of Audit and Governance Committee (AGC) on the performance of internal Shariah auditors among Islamic banks. The researcher has used an Islamic worldview based and Islamic accountability theory to understand this subject. The paper proposes that AGC in terms of its independence, qualification and experience may impact Islamic banks' internal Shariah audit performance. This study makes a contribution to the literature of Shariah auditing, particularly of internal Shariah auditing's performance. It also tries to examine the impact of AGC on internal Shariah audit performance from Islamic point of view.
\end{abstract}

Index Terms: Islamic Worldview; Islamic Accountability Theory; Internal Shariah Audit; Performance; AGC.

\section{INTRODUCTION}

The collapse of big companies like Worldcom and Enron has resulted in the emphasis on internal audit. Hence, creating an increase in the demand for internal Shariah auditors for their supervisory role. Consequently, this has resulted in the requirement of investment in internal auditing by Islamic banks, and improvement in the freedom of these auditors in ensuring the attainment of organizational goals (Rahman, 2011). The notion of these auditors' independence is associated with the Islamic worldview. Generally, the various socio-economic behaviors and economic objectives as well as the multiple policy recommendations and theoretical frameworks are results of an array of worldviews (Umer, 2000). A discourse on Islamic worldview can assist in clarifying the framework where the principles of Islamic accounting and reporting being established (Maliah, 2005). All Muslims subscribed to the principle of Tawheed, Oneness (of God), i.e. Allah s.w.t. Here, the greatest being is Allah, where there is no other God but Him. He made the humans and established guidelines that govern them.

Al-Attas (1978) states that Islam is about the way of life. The foundation of Islamic teaching is static. However, subjects such as finance, management and economics are flexible, and they change over time and across situations. The obvious regulations and norms remain unchanged in accordance to al-Quran and Sunnah, while their values must

Revised Manuscript Received on September 22, 2019.

Azam Abdelhakeem Khalid, Department of Accounting and Finance, Faculty of Management and Economics, Universiti Pendidikan Sultan Idris, 35900Tanjong Malim, Perak, Malaysia, azamabdelhakeem@gmail.com. be centered upon Islamic worldview, such as the notion of religion (ad-Din) (Mohamed, 1997). The perspectives of Western secularist (religion is unrelated to other pursuits) and materialistic worldview differ from Islam; in which Islam has two distinct notions, i.e. this world, and hereafter (judgment day) (Ibrahim, 2000). As such, in accordance to Islamic-worldview theory, this study will develop a conceptual framework for the performance of internal Shariah audit.

\section{LITERATURE REVIEW}

\section{A. Islamic Worldview Based}

In our everyday lives, the worldview's function is vital. In our every pursuit, worldview will have an influence on it. It is about how we perceive and comprehend the events happening around the world, particularly those related religion, as well as political views and notions. In principal, it differs from the one of the Western's (Htay \& Salman, 2013). Al-Attas (1978) states that for Islamic worldview, it is a "vision of reality and truth" (ra'yat al-Islam li al-wujud). It is further interpreted by him that Islamic worldview is " $a$ metaphysical survey of visible as well as the invisible worlds including the perspective of life as a whole, is not a worldview that is formed merely by the gathering together of various cultural objects, values and phenomena into artificial coherence”. (p. 26). As such, in regard to Islamic ontology (being in existence), the Islamic worldview sees from two different contexts, this world (universe), and hereafter (Judgment day). The essential element of Islamic worldview is Tawhid (Unity of Allah) (Anuar, Sulaiman, \& Ahmad, 2009; Chapra \& Chapra, 1992), and everything else is just an extension to it, i.e. Khalifah (vicegerent), 'Abd (slave of God), Justice, Nature, Falah and so on. In view that Al-Quran is the principal reference of Islamic worldview; Islamic worldview is also known as Quranic worldview.

The first element which is the fundamental and highest principle of Islam is Tawheed (Unity of Allah). Here, Allah is the One, He creates and owns the universe; Islam dictates a total yielding to Him in all our pursuits (Hameed, Wirman, Alrazi, Nazli, \& Pramono, 2007; Maali, Casson, \& Napier, 2006; Muwazir, Muhamad, \& Noordin, 2006). From the perspective of Shariah, the unification of Allah is stressed on accountability, and this encompasses the bond with Allah, and bonds with other

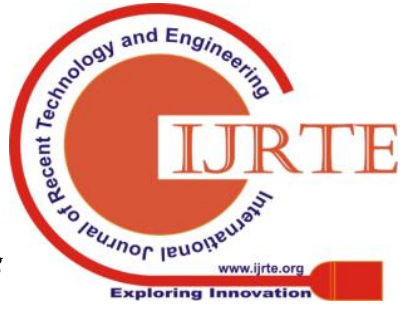


beings. Moreover, the notion about Allah can be expanded to financial, political and socio-economic relationships, as well as between the Islamic banks' management and shareholders. As such, all IFIs' activities must be consistent with the principles and guidelines set by Islam. This is because these activities have an impact on the community (Ummah), the Muslims in particular (Rahman \&Bukair, 2013).

Khalifah (Caliph) is a concept that signifies one's situation or role, and identifies his responsibility to himself as well as to the Ummah. In accordance to this notion, Allah is the unrivalled owner of every existence; and we are answerable and liable to Allah (Maali et al., 2006; Muwazir et al., 2006). Despite the Muslims being permitted to own privately, there is no ownership in totality. We are only vicegerents that Allah put onto this world and are the trustees with the right to utilize. We are also required to protect the earth. Allah has bestowed upon us the right to utilize, i.e. not the right to ownership. With this, we are accountable and answerable as Allah has established certain guidelines for us to adhere to. The word 'caliph' (Khalifah) for business entities means that organizational resources are to be utilized by the managers in accordance to the laws stipulated by Allah (Muwazir et al., 2006).

The notion of brotherhood (Akhowa) from Islamic worldview's perspective is about fairness and social accountability (Muwazir et al., 2006; Maali et al., 2006). Al-Quran states that: "All Muslim are considered to be brothers" (49:10). In a society, each Muslim is to be liable to each other. This meaning has been explained by a Hadith "The Muslim in their mercy towards each other is like a body, if a single part of it complains the other part would be affected". In Islam, there are various examples of the practices of social fairness and these include averting usury (Riba), interest free borrowings (Quard Hassan) and religious tax (Zakah). Consistent with social fairness, business entities run by Muslims must have a fair dealing with everyone including the shareholders, staff, customers and others in the society. Hence, the Islamic worldview's three foundations will have an impact on IFIs in their pursuits, especially through the announcement of their information via yearly reports (Rahman \& Bukair, 2013).

Islamic worldview underlies everything in Islam. It corroborates the nature of Islam itself which is comprehensive, all pervasive and inextricable from sacred and profane; creation and purpose (worship); knowledge and action; and life now and hereafter. In any Islamic discipline of knowledge, the field of knowledge should be underlined by Islamic worldview and vision (Hameed et. al., 2007). Most of the time, the literature will refer to Islamic worldview. This is because the vision is directly derived from the Islamic worldview that forms the elements of the worldview itself. The involvement of Islamic worldview has a positive contribution to the internal Shariah audit performance. The code of ethics that is in accordance to Quran and Tawheed values is a must for every Muslim. In Islamic teaching that there is dual-responsibility, one to Allah and the other is to other human beings; and they are the most perfect answer in achieving a quality audit for IFIs.

\section{B. Auditing From Islamic Point View}

An audit that is based on Islamic Shariah provides the entity with the advice and supervision on the compliance of its operation to be within Islamic guidelines. There is a glaring difference between Islamic and Western practices as highlighted by Islamic laws. For example, Islam does not allow the practice of usury (riba) (Quran 2: 275-276), gamble (Quran 5:90), amassing (Quran 9:34) and betting (Qureshi, 1976). In addition, Islam does not allow the investments or the dealings associated with pork, alcohol and other pursuits considered haram. In view that organizations need to comply with Islamic laws, Shariah audit is a must. If the auditors discover any non-compliant activities, the Shariah supervisory board (SSB) shall be informed. Shariah audit is done in accordance to the guideline stipulated by the Accounting and auditing organization for Islamic financial institutions (AAOIFI). It is an investigation over the degree of compliance of all activities with Islamic laws. This will encompasses all agreements, transactions, policies, financial statements, products and memorandum and article of association. As IFIs have to operate under Islamic worldview, a different set of accounting method is needed (Ibrahim, 2000), as well as audit methodology (Kahn, 2001). These methods will fulfil the requirement of Muslims in which their concentration and precedence differ from others ((Kasim, Ibrahim, \& Sulaiman, 2009).

\section{Shariah Auditing in Islamic Banks}

IFIs' formation has caused various significant changes, this is particularly true in their operating methods (Karim, 2001) and goals (Harahap, 2002). These have consequently influenced their auditing method (Karim, 2001). Nowadays, the auditing of these institutions is locally governed; with some institutions have partial compliance, while others at full compliance with AAOIFI's guidelines. It has been considered that the standards stipulated by AAOIFI are the most applicable for Shariah auditing. In addition to internal Shariah auditors, the external auditors are also liable to financial auditing. Meanwhile, the SSB is operating in-house in the IFIs to ensure their compliance. Presently, consistent with the IFIs' rapid growth, this type of auditing has become a vital topic of discourse.

Business entities with well-functioned internal auditors are in better position as compared with those entities without these auditors. This is because they will encounter challenges that are connected to fraud, as well as its recognition and avoidance (Corama, 2006; Maria, 2012; Omar \& Bakar, 2012). Auditors are tasked with ensuring that the internal regulation mechanism in terms of Shariah conformity is good and effective; and this is done through consistent scheduled investigation (Rahman, 2011). Internal audit department does only not play a role in ensuring corporate governance and giving advices internally (Stewart \& Subramaniam, 2010), the department also covers Shariah auditing to make sure the organizations adhere to Islamic

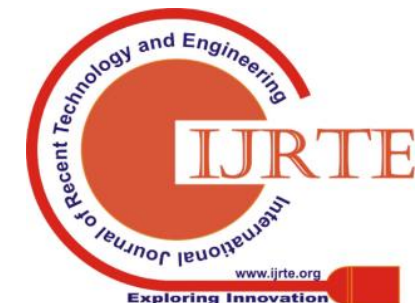


laws. The auditors must be satisfied and make a sound appraisal that all the investigated activities are in compliance with Shariah (Yahya \& Mahzan, 2012). The role of Shariah audit is filled by those IFIs' internal audit department. For external parties be confident in the auditors' impartiality, they must be capable to show that their freedom is not in danger (Messier, 2002; Arens, 2008).

\section{Internal Shariah Audit Performance}

Consistent with the IFI governance standards issued by AAOIFI (2010), i.e. No. 3, the planning of internal auditing related to Shariah compliance must be undertaken by those internal Shariah auditors. In the establishment of the internal Shariah audit's goals and scope, the documents related to planning have to encompass, among others, activities' background information like the locality, departments, products/services, divisions, branches and others. In addition, information pertaining to the fatws and directives issued by the SSB, previous year's audit findings, as well as applicable communication that include controlling bodies are all required. The resources needed in conducting the audit also need to be identified. Moreover, all staff need to be informed about the audit. A survey also needs to be undertaken as to familiarize on the audit areas being emphasized on, as well as welcoming feedbacks from auditees. The audit itinerary also needs to be written down. Also, the auditors need to determine the method and timeframe when the findings will be communicated. Lastly, a consent is needed on their audit planning from the management, as well as the SSB.

During the audit process, the auditors have to gather and examine the information to back their audit findings. The information must encompass all the matters relevant to their audit's goals and scope; and these include documents' inspection, evaluation, probes, discourses with management, as well as observation. The information being gathered has to be satisfactory, dependable, applicable and helpful in providing strong audit's outcomes. The reports are prepared by these auditors and assessed by the internal Shariah audit department's chief. These reports have to support the audit's results and suggestions; and are to be adequately prepared, finalized, arranged, assessed and filed (AAOIFI, 2010). The manager of internal Shariah audit will have a discussion with the management before a final assessment is issued. Upon the conclusion of the audit, a quarterly report needs to be issued and approved by the internal Shariah audit department's chief. It has to be addressed to the BOD, with a copy each to the management and SSB. The report has to impartial, obvious, helpful and within stipulated timeframe. It has to contain the goals, scope and outcomes as well as the auditors' opinion. There must also be suggestions for improvements and activities needed to correct the errors; as well as acknowledgement of good job execution, whenever suitable.

The feedbacks from the auditees pertaining to the audit's conclusion or suggestions must also be incorporated into the audit report prepared by the internal Shariah auditors. All disagreements on Shariah matters shall be referred to SSB. There shall be a monitoring by the internal Shariah audit to ensure that actions have been taken on their suggestions and findings. In fact, all other Shariah-related findings discovered by the external auditors, controlling bodies as well as the SSB must have follow-ups. As such, the role played by internal auditors in Shariah-related matters has to also include the direct and consistent interactions with everyone related to the auditing. Their job scope should be broad and they must have full access to all activities in the IFIs. Only then, the internal Shariah auditors can do their jobs effectively and efficiently.

\section{E. Audit \& Governance Committee (AGC)}

Theoretically, the role of AGC (also known as Audit Committee) is in conformity with the notion of accountability in Islam. It is to help the BOD executes an impartial and independent supervision through these roles: 1) the integrity of the processing of finan ial statement is preserved; 2) protect the stakeholders' interest; 3 ) an effective AGC is able to provide added affirmation on the financial data given to the BOD; and 4) an independent party to the relationship the IFI's senior managers and stakeholders. The vital role of ACG emerged due to its function of attaining the basic goals of the IFIs. This is done by providing better transparency and greater coverage of financial disclosures, hence strengthening the confidence in the IFI's compliance with Islamic laws (AAOIFI, 2010).

It has been stressed by the AAOIFI (2010) that AGC is to assess the internal auditors so that IFIs will have an adequate supervision on all their activities. This includes ensuring that the internal auditor is functioning well and the control is effective, as well as supervising the execution of strategies. The committee must have an adequate knowledge about the business and the control environment for it to able to make important assessment on the internal control system. It needs to acknowledge the findings of both external and internal auditors as well as assess these findings. The committee is also to review the resources, capabilities, job scope, general outlook and reporting line of internal auditors as well as to assess the internal control mechanism's efficiency. Its concentration are mainly on significant audit results, letters of external auditors and other vital reports from controlling authority together with the management's feedbacks.

The AGC functioned as a reviewer to the accounting practices, and audit proposal, particularly the auditors' assessment role and scope. This is specifically related to hazardous location as well as the auditors' resources and capabilities; the cooperation between the IFIs' own auditors and the outside auditors, and ensure that the auditors' freedom and professional integrity are intact. The committee also has to consider the selection, resignation and removal of its members, as well as the head internal and/or external auditors. It also needs to assess the new appointments (AAOIFI, 2010).

The creation of AGC varies in accordance to every IFI and the nation where it is formed. It is established by the non-executive directors. Meanwhile, the committee's

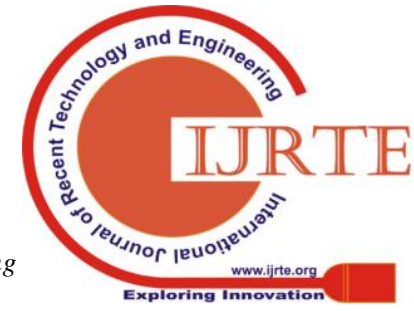


chairman will be appointed by the BOD. The committee is given the authority to execute its responsibilities with freedom and integrity. The terms of the BOD's members are matched by the AGC. It has to consist of more than three persons, representing a balanced perspective and experience. Its members must be experts in the business, as well as the regulations and guidelines for them be able to have adequate dealing with matters related to accounting and auditing. They must also have the understanding of Islamic laws, the Islamic products and services that apply these laws as well as the AAOIFI's rulings. In regard to the committee's meeting, BOD's consent must be obtained where internal by-laws are prepared to monitor these meetings, and who must participate in these meetings but, without vote rights. The AGC's reports must be given to the BOD through the chairman, with a copy to the CEO. It is also suggested that the committee's chairman to report to the BOD's chairman on all major issues discussed during the previous meeting. The BOD must have discussions on AGC's work in accordance to the quarterly report. There is a new interest pertaining to corporate governance of Islamic banks, especially the audit and governance committee. This is because the committee encompasses professionals who are independent, knowledgeable and highly qualified. Therefore, an Islamic bank with competent board can improve the internal Shariah auditors' independence (Safieddine, 2009).

There are proofs that show the positive link between audit committee and independent auditors. The positive link between audit and governance committee and the performance of internal Shariah auditors signifies that the committee will improve these auditors' performance. Teoh and Lim (1996) have discovered that the establishment of audit committee strongly and positively affect auditors' independence. Meanwhile, Goodwin and Yeo (2001) have discovered that an audit committee that is effective will enhance internal auditors' roles. This is because it acts as an impartial party where internal auditors can raise issues that impact the management.

\section{Audit and governance committee and internal Shariah audit performance in light of Islamic accountability theory}

The vital area of corporate governance is accountability. In a hadith by Prophet (S.A.W), "Each one of you is a guardian, and each guardian is accountable to everything under his care. Applying His words in today's context, those involved in business transactions are responsible for their actions. Hameed (2001) defines Islamic accountability as that of a dual nature because the primary accountability is towards God where man is a khalifah (trustee), entrusted with resources. The secondary accountability involves a contractual relationship and it could be between an owner (investor) with a manager or employees and management. In Islamic economic and political systems, Shariah is the essential guiding force as it encompasses all aspects of human life. As stated in the Holy Quran, 2:284, all of us will ultimately be accountable to Allah and we will be answerable to Allah for our deeds. To Allah belongs whatever is in the

Heavens and whatever is in the Earth. Whether you show what is within yourselves or conceal it, Allah will bring you to account for it.

According to Chapra, Khan, and Al Shaikh-Ali (2008) Muslims should be highly motivated and not rationally sacrificed their value in the long term to achieve a short term value in this temporal world. All Muslims are accountable for their individual and collective actions in this world (Al-Safi \& Badawi, 1992). Al-Safi and Badawi (1992) have quoted the following verses from the Quran to reflect the accountability of an individual within one's capacity: $\mathrm{Al}$ Baqarah (2:233 and 286), Al Nisa (4:84), Al An'am (6:52), and Al Talaq (65:7). Thus, Islamic accountability of an individual is based within the limits of one's capability(Al-Safi \& Badawi, 1992). An individual is accountable for his own deeds. Essentially, the Islamic accountability is applicable to every facet of life. Therefore, in conceptualizing internal Shariah audit performance, which is a part of corporate Shariah governance in Islamic banks, the internal Shariah auditor is accountable to Allah SWT and His creations - both Muslim and non-Muslims, the society, and the environment, specifically AGC.

\section{CONCEPTUAL FRAMEWORK}

The aim of Islamic accountability is two-fold, namely, that to creator -Allah SWT, and that towards His creations -mankind, as well as in terms of social and environmental aspects. Islamic accountability is closely interrelated with the application of Tawheed (Oneness of God) (Alam Choudhury \& Ziaul Hoque, 2006; Omer, 2010; Sulayman, 1998). Epistemologically, Islamic accountability is derived directly and extended from Tawheed. The Tawheed drives mankind to excel/Falah because it is a formation of ethics of both intention and action. As a theory, Islamic accountability has several concepts. This paper extends the original concepts of the theory to the topic under study. In addition, other related concepts under study that not being categorized under any essential elements of Islamic worldview before are assigned appropriate essential elements of Islamic worldview (of Nature and Falah). The following Table 1 shows the essential elements of Islamic worldview that underlay the theory, original concepts and extended concepts as conceptualized in this paper.

\begin{tabular}{|c|c|c|c|}
\hline Theory & Concepts & Original & Extended \\
\hline Islamic & Creator: & Allah & Allah \\
\hline Accountability & Primary & & \\
\hline (Based on the & Accountee & & \\
\hline essential elements & Created: & Accountants & Internal \\
\hline of worldview - & Primary & & Shariah \\
\hline Creator (Allah) and & Accountor & & Auditors \\
\hline $\begin{array}{lr}\text { His } & \text { creations } \\
\text { [human, } & \text { religion, } \\
\text { nature } & \text { and }\end{array}$ & $\begin{array}{l}\text { Created: } \\
\text { Secondary } \\
\text { Accountee }\end{array}$ & Stakeholders & $\begin{array}{l}\text { Audit and } \\
\text { Governance } \\
\text { Committee }\end{array}$ \\
\hline
\end{tabular}


objective])

$\begin{array}{ll}\text { Created: } & \text { Islamic } \\ \text { Nature } & \text { Accounting } \\ & \text { field }\end{array}$

Shariah field

Created: Falah/Success independence experience Objective Social welfare performance

Based on the discussion in the preceding sections and in line with the explanation of the theory with regard to the conceptual relationship between AGC and internal Shariah audit performance; the following conceptual framework is developed (Figure 1) and corresponding propositions are consequently formulated.

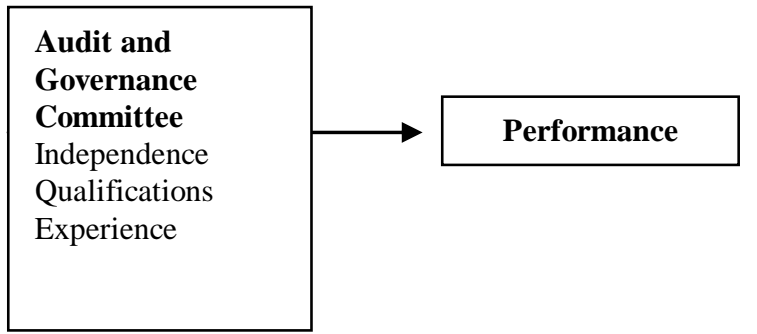

Fig 1: Conceptual framework of relationship between AGC and internal Shariah audit performance in Islamic banks in the light of Islamic accountability theory

\section{Proposition}

P1 Audit and governance committee positively impacts on internal Shariah audit performance in Islamic banks

P1a Each dimension of AGC has positive impact on internal Shariah audit performance.

\section{DISCUSSION AND CONCLUSION}

The paper examines the impact of audit and governance committee on internal Shariah audit performance in Islamic banks under Islamic-worldview-based theory, i.e. Islamic accountability. Literature review shows limited number of studies being done on audit and governance committee, particularly those related to internal audit performance in Islamic banks. This paper is an effort towards adding more literature on the subject under study. Additionally, it also contributes towards a better understanding of internal Shariah audit performance in Islamic banks which requires different set of human capital. This paper propounds that Islamic accountability theory could be used in building a conceptual framework of internal Shariah audit performance (primary accountor). Meanwhile, independence, qualifications and experience, and audit \& governance committee (AGC) are conceptualized as Nature, Falah, and secondary accountee, respectively. Performance could be enhanced by more independent, better qualified and experienced internal Shariah auditors. Experience as part of Nature in Islamic worldview should be utilized to make audit related decisions and is performed not only for others but also the primary accountee, Allah.

Due to the position of AGC as the ultimate supervisor in the IFIs, the AGC could impact the performance of internal Shariah auditors. Thus, it is further proposed that audit and governance committee is stronger at higher level based on Islamic accountability theory. As this is a conceptual paper, the proposed conceptual framework needs to be verified empirically. Additionally, more of nature and/or secondary accountee variables of Islamic accountability theory can be added to this conceptual framework. These variables are such as competency of internal Shariah audit, scope of internal audit, SSB and Shariah's compliance officer.

\section{REFERENCES}

[1] AAOIFI. (2010). Accounting, auditing and governance standards for islamic financial institution. . Manama, Bahrain.

[2] Agarwal, G. K., \& Medury, Y. (2014). Internal auditor as accounting fraud buster. IUP Journal of Accounting Research \& Audit Practices, 13(1).

[3] Al-Attas, M. N. (1978). Islam and secularism: muslim youth movement of malaysia Kuala Lumpur.

[4] Al-Safi, O. A., \& Badawi, M. (1992). Accountability: a comparative study of human responsibility between islam and man-made doctrines: Darulfikir.

[5] Alam Choudhury, M., \& Ziaul Hoque, M. (2006). Corporate governance in Islamic perspective. corporate governance: The International Journal Of Business In Society, 6(2), 116-128.

[6] Anuar, H., Sulaiman, M., \& Ahmad, N. N. (2009). Some evidence of environmental reporting by shariah compliant companies in malaysia. IIUM Journal of Economics and Management, 17(2), 177-208.

[7] Arens. (2008). Auditing and assurance services financial services: in Malaysia : an integrated approach. Kuala Lumpur.: Prentice Hall, .

[8] Chapra, M. U., \& Chapra, M. U. (1992). Islam and the economic challenge: Islamic Foundation Leicester.

[9] Chapra, M. U., Khan, S., \& Al Shaikh-Ali, A. (2008). The islamic vision of development in the light of maqasid al-shariah (Vol. 15): Iiit.

[10] Corama, P., C. Fergusona and R. Moroney, . (2006). The value of internal audit in fraud detection. Journal of Accounting and Finance,, 48((4)), 543-559.

[11] Goodwin, J., \& Yeo, T. Y. (2001). Two factors affecting internal audit independence and objectivity: evidence from Singapore. International Journal of Auditing, 5(2), 107-125

[12] Hameed, S. (2001). Islamic accounting-accounting

[13] for the new millennium? Paper Presented At The Asia Pacific Conference.

[14] Hameed, S., Wirman, A., Alrazi, B., Nazli, M., \& Pramono, N. (2007) Alternative disclosure and performance measures for islamic banks. International Islamic University Malaysia.

[15] Harahap, S. S. (2002). Auditing dalam perspektif islam (auditing in the islamic perspective): Pustaka Quantum.

[16] Htay, S. N. N., \& Salman, S. A. (2013). Transaction cost theory, political theory and resource dependency theory in the light of unconventional aspect.

[17] Ibrahim, S. H. M. (2000). Nurtured by 'Kufr': The western philosophical assumptions underlying conventional (Anglo-American) accounting. International Journal of Islamic Financial Services, 2(2), 19-38.

[18] Karim, R. A. A. (2001). International accounting harmonization, banking regulation, and Islamic banks. The International Journal of Accounting, 36(2), 169-193.

[19] Kasim, N., Ibrahim, M., Hameed, S., \& Sulaiman, M. (2009). Shariah auditing in islamic financia institutions: exploring the gap between the" desirable" and the" actual". Global Economy \& Finance Journal, 2(2), 127-137.

[20] Kasim, N., Ibrahim, S. H. M., \& Sulaiman, M. (2009). Shari'ah auditing in islamic financial institutions: exploring the gap between the 'desired'and the 'actual'. Global Economy and Finance Journal, 2(2), 127-137.

[21] Khan, M. A. (2001). Role of supreme audit institutions in shaping the Islamic economy in the 21 st Century. IIUM Journal of Economics and Management, 9(1), 77-100.

[22] Libby, R., \& Frederick, D. M. (1990). Experience and the ability to explain audit findings. Journal of Accounting Research, 348-367.

[23] Maali, B., Casson, P., \& Napier, C. (2006). Social reporting by islamic banks. abacus, 42(2), 266-289.

[24] Maliah, S. (2005). Islamic corporate reporting: between the desirable and the desired: International Islamic University Malaysia.

[25] Maria, R. (2012). Corporate governance, internal audit and environmental audit-the performance tools in Romanian companies. Corporate Governance, 11(1), 112-130.

[26] Messier, W. F. a. M. B. (2002). Auditing and assurance services in Malaysia. Kuala Lumpur.: $2^{\text {nd }}$ ed. McGraw Hill,.

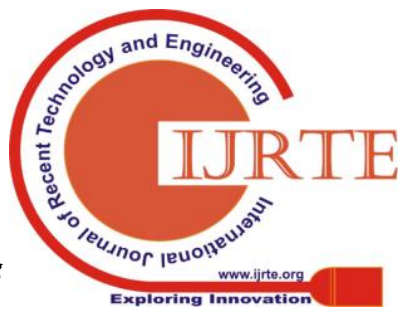


[27] Mihret, D. G., \& Yismaw, A. W. (2007). Internal audit effectiveness: an ethiopian public sector case study. Managerial Auditing Journal, 22(5), 470-484.

[28] Mohamed, H. M. A. (1997). Islam, the Islamic worldview and Islamic economics. IIUM Journal of Economics and Management, 5(1), 39-66.

[29] Muwazir, M. R., Muhamad, R., \& Noordin, K. (2006). Corporate social responsibility disclosure: a tawhidic approach. Jurnal Syariah, 14(1), 125-142.

[30] Omar, N., \& Bakar, K. M. A. (2012). Fraud prevention mechanisms of Malaysian government-linked Companies: an assessment of existence and effectiveness. Journal of Modern Accounting and Auditing, 8(1), 15-31.

[31] Omer, S. (2010). A conceptual framework for sustainability in Islamic architecture: The significance of the Islamic concepts of man and the environment.

[32] Rahman, A. (2008). Shari'ah audit for Islamic financial services: the needs and challenges. Paper presented at the ISRA Islamic Finance Seminar Mandarin Hotel, Kuala Lumpur.

[33] Rahman, A. R. A. (2011). Enhancing the integrity of

[34] Islamic financial institutions in Malaysia: The Case for Shariah Audit Framework. ISRA International Journal of Islamic Finance, 3(1), $135-147$.

[35] Stewart, J., \& Subramaniam, N. (2010). Internal audit independence and objectivity: emerging research opportunities. Managerial Auditing Journal, 25(4), 328-360.

[36] Sulayman, A. H. A. A. (1998). The theory of the economics of Islam (I). International Journal of Economics, Management and Accounting, 6(1).

[37] Teoh, H. Y., \& Lim, C. C. (1996). An empirical study of the effects of audit committees, disclosure of nonaudit fees, and other issues on audit independence: Malaysian evidence. Journal of International Accounting, Auditing and Taxation, 5(2), 231-248.

[38] Umer, C. M. (2000). The future of economics: an islamic perspective.

[39] Yahya, Y., \& Mahzan, N. (2012). The Role of internal auditing in ensuring governance in Islamic Financial Institution (IFI).

\section{AUTHORS PROFILE}

Azam Abdelhakeem Khalid is a Senior lecturer at the Universiti Pendidikan Sultan Idris (UPSI). He was conferred a $\mathrm{PhD}$ from Universiti Sain Malaysia (USM), in 2016 with specialization in Shariah auditing. He carries with his more than 8 years of academic experience at Delmon University for Science and Technology, Kingdom of Bahrain and Lincoln University College, Malaysia. He conducts research in the areas of Shariah auditing, Islamic accounting and Waqf. Dr Azam has published more than 10 papers in well-respected international journals. He also serves as an external evaluator, reviewer and examiner for $\mathrm{PhD}$ and accounting program locally and internationally. 